\title{
Graduate skills requirements for effective performance in the banking sector
}

\author{
Elif Cicekli ${ }^{1}$ \\ 1 Department of Management, Faculty of Business, Istanbul Bilgi University Kazim Karabekir Cad. No: 2/13, 34060 Eyup, Istanbul, Turkey \\ Corresponding author: ElifCicekli(elif_cicekli@yahoo.com)
}

Received 18 September 2015

Accepted 11 April 2016

Published 10 November 2016

Academic editor:

Živile Tunčikiené

Keywords

banking

human resources

skills

new graduates, managers

JEL Classification

\begin{abstract}
This paper aimed to explore the graduate skills requirements in the banking sector. Indepth interviews were carried out with twenty-five managers in ten companies in the banking industry in Turkey. The results show that 40 percent of managers thought universities do not provide their graduates with the skills necessary to be successful in their jobs. Soft skills (i.e. communication, interpersonal relationship, and teamwork skills) are particularly sought after, and managers would also like to see more training in analytical thinking skills. Researchers are recommended to study the subject in different counties using quantitative methods. Based on results, bank executives are advised to communicate and collaborate with educators to make sure their needs are known and met. This paper filled the gap in research on the skills the banking sector needs in new graduates.
\end{abstract}

J24, M12, M51

\section{Introduction}

Human resources have a significant impact on organizations' performance (Stankevičienė et al. 2009). Universities are increasingly expected to provide highly mobile graduates who can respond to the constantly changing needs of contemporary organizations (Andrews and Higson 2008), but whether new graduates' qualifications meet these needs is a matter of debate (Hesketh 2000). To be able to meet employers' needs, university students and educators need to know what these needs are. Hence, research is needed to clarify what employers need from their new-graduate human resources (HR). Although studies have been conducted on whether university graduates have the necessary skills to be successful in their jobs, no study has addressed this issue as it relates to the banking sector in particular. The aim of this paper was to fill this gap in the research by answering three questions related to the banking industry:

1. What skills do managers in the banking sector seek in newly graduated job candidates?
2. Do managers think that universities provide their graduates with the skills necessary to be successful in their jobs in the banking sector?

3. For which skills would managers like more training to be provided at the universities?

In order to answer these questions, in-depth interviews were carried out with twenty-five managers in ten companies in the banking industry in Istanbul, Turkey.

\section{Literature review}

Most of the research on new graduate needs of employers do not concentrate on the skills but rather the qualities employers seek. These qualities include skills, and many other issues such as personality characteristics (Daud et al. 2011; Norwood and Henneberry 2006), attitudes (Coetzer and Sitlington 2014; McMurray et al. 2016; Kavanagh and Drennan 2008; Kirk and Chapman 1992), degrees earned (Norwood and Henneberry 2006), knowledge in various areas (A1 Shayeb 2013; Coetzer and Sitlington 2014; Ras- 
suli et al. 2012; Thomas and Nicita 2003), extracurricular activities, grades (McMurray et al. 2016; Rivera 2011), previous work experience (Andrews and Higson 2008; Cook and Finch 1994; Kirk and Chapman 1992; Morley and Aynsley 2007), and the prestige of the candidate's alma mater (Morley and Aynsley 2007; Rivera 2011).

Most of the studies that have focused exclusively on the skills sought from new graduate job candidates have focused on what skills are needed from graduates of specific education programs, such as business (Rassuli et al. 2012; Tanyel et al. 1999), economics (Hellier et al. 2004), accounting (Jackling and De Lange 2009; Ngoo et al. 2015), engineering (Husain et al. 2010), operations research (Sodhi and Son 2008), and veterinary (Bachynsky et al. 2013) programs and only a few on the needs of various types of employers. Only a few have focused on skills required in particular industries or professions, such as manufacturing (Sullivan 2012), knowledge-intensive industries (Collet et al. 2015), and accounting (Klibi and Oussii 2013).

The few studies that target the banking industry do not focus on the skills needed in the banking sector per se. Rassuli et al. (2012) studied the skills and knowledge expected from business graduates in general, as their US sample consisted of managers from banking and six other industries. Adebakin et al. (2015) studied required skills for graduates in Nigeria, but their sample consisted of managers from banking and three other industries. Cicekli (2015) studied what banks require of new graduates in Turkey but focused only on the types of knowledge that managers would like new graduates to have, not the skills.

The extant studies on the skills needed from new graduates have shown that employers seek generic skills that can be applied in a variety of jobs or industries, rather than skills that are job-specific. Only a few studies have reported on the job-specific skills employers require, including accounting analysis skills (Jackling and De Lange 2009), skills in basic science (Kirk and Chapman 1992), and research skills in operations management, modelling, statistics, and programming (Sodhi and Son 2008). The skills employers seek from new graduates usually include generic skills like communication (Andrews and Higson 2008; Hesketh 2000; Jackling and De Lange 2009; Kavanagh and Drennan 2008; Kirk and Chapman 1992; Morley and Aynsley 2007; Norwood and Henneberry 2006; Sodhi and Son 2008; Thomas and Nicita 2003), team-working (Andrews and Higson 2008; Hesketh 2000; Jackling and De Lange 2009; Morley and Aynsley 2007; Thomas and Nicita 2003), and interpersonal skills (Hellier et al. 2004; Husain et al. 2010; Morley and Aynsley 2007; Tanyel et al. 1999), all of which are soft, "people" skills. Other general skills that many employers seek include analytical thinking (Andrews and Higson 2008), problem-solving (Andrews and Higson 2008; Hesketh 2000), learning, self-management, numeracy (Hesketh 2000), writing (Hellier et al. 2004; Thomas and Nicita 2003), data analysis (Hellier et al. 2004), information technology (Andrews and Higson 2008; Hesketh 2000), decision-making (Kavanagh and Drennan 2008), and time-management (Tanyel et al. 1999) skills.
The latest research results show that employers value some skills more than others. Collet et al. (2015) studied the skills required from graduates in the research industry using a sample of 207 managers in Australia and found a gap between the skills organizations require and those that the graduates have. They also found that what mattered most to managers was whether the graduates fit into the organizations' structures, strategies, and culture, and that fit was dependent on cognitive and personal skills. Ngoo et al. (2015) studied the issue with fifty employers in Malaysia and found that, among the list of the non-technical skills provided, the most important skills employers sought in accounting graduates were communication, critical thinking, and problem-solving skills. Adebakin et al. (2015) studied skill requirements with a sample of 300 employers in Nigeria and found that the most important skills were information and communication technology, teamwork, decision-making, and analytic and problem-solving skills. The graduate skills that employers rated as poor were team work, risk management, leadership, and decision-making skills. McMurray et al. (2016) studied the graduate skill requirements with a sample of seventy-two employers in Scotland and found that the most important skills employers sought in business graduates were communication, adaptability, teamwork and interpersonal skills. The employers reported that the areas that needed most to be addressed in terms of graduates' skills were communications, teamwork, numeracy, and language skills.

Thus, employers seek generic skills from graduates and the most recent research results have shown that the most important generic skills for employers are communication skills (McMurray et al. 2016; Ngoo et al. 2015); team-work skills (Adebakin et al. 2015; McMurray et al. 2016); cognitive, interpersonal and intrapersonal skills (Collet et al. 2015); critical thinking and problem solving skills (Ngoo et al. 2015); information and communication technology, decision-making, analytic, and problem-solving skills (Adebakin et al. 2015); and interpersonal and adaptability skills (McMurray et al. 2016). Employers reported that graduates are not sufficiently skilful in many areas (Adebakin et al. 2015; Collet et al. 2015; McMurray et al. 2016).

In summary, although there have been many studies (Adebakin et al. 2015; Al Shayeb 2013; Andrews and Higson 2008; Bachynsky et al. 2013; Coetzer and Sitlington 2014; Cook and Finch 1994; Collet et al. 2015; Daud et al. 2011; McMurray et al. 2016; Hellier et al. 2004; Husain et al. 2010; Jackling and De Lange 2009; Kavanagh and Drennan 2008; Kirk and Chapman 1992; Klibi and Oussii 2013; Morley and Aynsley 2007; Norwood and Henneberry 2006; Ngoo et al. 2015; Rassuli et al. 2012; Rivera 2011; Sodhi and Son 2008; Sullivan 2012; Tanyel et al. 1999; Thomas and Nicita 2003) on what employers need from new graduates, few focus on skills so much as qualities. A few studies (Adebakin et al. 2015; Bachynsky et al. 2013; Collet et al. 2015; Hellier et al. 2004; Husain et al. 2010; Jackling and De Lange 2009; Klibi and Oussii 2013; Ngoo et al. 2015; 
Rassuli et al. 2012; Sodhi and Son 2008; Sullivan 2012; Tanyel et al. 1999) concentrate on the specific skills employers need, but most of these explore the skills needed from graduates of specific degree programs, so they have an education-program focus. A few also examine the skills needed for a specific profession or industry (Collet et al. 2015; Klibi and Oussii 2013; Sullivan 2012), but those that deal with the banking industry (Adebakin et al. 2015; Cicekli 2015; Rassuli et al. 2012) either do not explore required skills but focus on knowledge needs or simply include the banking industry among several other industries. Hence, there is a gap in research on the skills that employers in the banking industry specifically need new graduates to have. It is important to explore the issue using qualitative research in order to identify in detail the job-specific and generic skills required of new graduates seeking employment in the banking industry to be able to meet the graduate skill needs.

\section{Methodology}

\subsection{Sample}

In-depth interviews were carried out with twenty-five managers in ten companies in the banking industry in Istanbul, Turkey. In six of the banks, foreign partners have a majority or all of the shares; in one, a foreign partner has the majority of the shares that are not publicly traded; and the remaining three are local banks with branches abroad. Eight of the banks' stocks are traded at Borsa Istanbul, and the rest are not publicly traded.

One bank had 500-999 employees, two had 1,000 9,999 employees, three had 10,000-14,999 employees, two had 15,000-19,999 employees, and one had 20,000 24,999 employees. One of the banks revealed only that the number of employees was above 500 .

Of the twenty-five managers interviewed, twenty-three $(92 \%)$ had job titles like manager, director, or executive. One of the two remaining managers was a vice president, and the other was an assistant manager. Eight managers $(32 \%)$ worked in finance related departments (i.e. finance, auditing, budgeting, funding and liquidity, and credit-related departments), seven (28\%) worked in marketing or sales departments, and five (20\%) worked in HR. Of the remaining managers, four $(16 \%)$ worked in product and process development, information management, private banking, or information technology, and one was a branch manager.

\subsection{Procedure}

Managers of the banks' HR departments were informed of the study's aims and asked to arrange meetings on a voluntary basis with the managers who worked in departments in which at least four new graduates had been recruited in the last five years. In-depth interviews with twenty-five managers provided data on the banks' skills requirements of new graduates. In the interviews, the managers were asked three questions:
1. What skills do they seek in newly graduated job candidates?

2. Do they think that universities provide their graduates with the skills necessary to be successful in their jobs in the banking sector?

3. For which skills would they like more training to be provided at the universities?

The interviews were recorded with the managers' permission, and the recordings were transcribed.

\section{Findings}

\subsection{Skills sought from new graduates}

Managers in the banking industry seek many skills from newly graduated job candidates, which are summarized in Table 1 . The twenty-five managers mentioned twenty separate skills at an average of 3.4 skills per manager (total of 85 responses). When considered in combination, soft skills were the most sought-after skill, as fifteen of the twenty-five managers (60\%) mentioned soft, "people" skills, such as communication (mentioned by 7 managers), interpersonal relationship skills, and teamwork skills (6 managers each). Some managers mentioned more than one of these skills.

The second most frequently mentioned skills were analytical thinking and foreign language skills, each of which were mentioned by almost half $(48 \%)$ of the managers. Of the twelve managers who mentioned foreign language skills, seven said English was a must, and two mentioned English plus preferably French. One listed English, German, or French, while another said English, German, or Russian was a requirement. One manager stated that foreign language skills are important in general but did not specify which languages were important. However, among the twelve managers who mentioned foreign language skills, all but one specified English as mandatory.

The third most commonly mentioned skill was computer skills. Of the eight managers who sought computer skills, seven mentioned skills in using MS Office programs, one required skills in using information technology, and one did not specify. Persuasion, $(20 \%)$, creativity $(16 \%)$, and speaking and diction skills $(16 \%)$ were also among the frequently mentioned skills. Other, less frequently mentioned skills can be seen Table 1 .

The results also show that the required skills do not change much from one department to another. As an exception to that, among the top skills required, computer skills were not mentioned by HR managers, and communication skills were not mentioned by marketing and sales managers. However, diverse skills such as analytical thinking, foreign language, interpersonal relationship, teamwork, persuasion, and speaking and dictation skills were mentioned by all department managers as required skills.

The rankings of the frequencies by which the skills were mentioned change from one department to another. Although analytical thinking skills were the most or 
Table 1. Skills sought from new graduates.

\begin{tabular}{|c|c|c|c|c|c|c|}
\hline Skills mentioned & $\begin{array}{l}\text { Finance related } \\
\text { departments }^{\mathrm{a}}\end{array}$ & $\begin{array}{c}\text { Marketing and } \\
\text { sales } \\
\text { departments }\end{array}$ & $\begin{array}{c}\text { HR } \\
\text { departments }\end{array}$ & $\begin{array}{c}\text { Other } \\
\text { departments }\end{array}$ & $\begin{array}{l}\text { Total number } \\
\text { of respondents }\end{array}$ & $\begin{array}{c}\text { Percentage of } \\
\text { respondents }\end{array}$ \\
\hline \multirow{2}{*}{ Analytical thinking skills } & $15.4 \%$ & $18.2 \%$ & $9.1 \%$ & $13.3 \%$ & \multirow{2}{*}{12} & \multirow{2}{*}{$48 \%$} \\
\hline & 4 & 4 & 2 & 2 & & \\
\hline \multirow{2}{*}{ Foreign language skills } & $11.5 \%$ & $18.2 \%$ & $13.6 \%$ & $13.3 \%$ & \multirow{2}{*}{12} & \multirow{2}{*}{$48 \%$} \\
\hline & 3 & 4 & 3 & 2 & & \\
\hline \multirow{2}{*}{ Computer skills } & $11.5 \%$ & $18.2 \%$ & - & $6.7 \%$ & \multirow{2}{*}{8} & \multirow{2}{*}{$32 \%$} \\
\hline & 3 & 4 & - & 1 & & \\
\hline \multirow{2}{*}{ Communication skills } & $7.7 \%$ & - & $13.6 \%$ & $13.3 \%$ & \multirow{2}{*}{7} & \multirow{2}{*}{$28 \%$} \\
\hline & 2 & - & 3 & 2 & & \\
\hline \multirow{2}{*}{ Interpersonal relationship skills } & $7.7 \%$ & $4.6 \%$ & $4.6 \%$ & $13.3 \%$ & \multirow{2}{*}{6} & \multirow{2}{*}{$24 \%$} \\
\hline & 2 & 1 & 1 & 2 & & \\
\hline \multirow{2}{*}{ Teamwork skills } & $3.9 \%$ & $4.6 \%$ & $13.6 \%$ & $6.7 \%$ & \multirow{2}{*}{6} & \multirow{2}{*}{$24 \%$} \\
\hline & 1 & 1 & 3 & 1 & & \\
\hline \multirow{2}{*}{ Persuasion skills } & $3.9 \%$ & $4.6 \%$ & $9.1 \%$ & $6.7 \%$ & \multirow{2}{*}{5} & \multirow{2}{*}{$20 \%$} \\
\hline & 1 & 1 & 2 & 1 & & \\
\hline \multirow{2}{*}{ Creativity skills } & $3.9 \%$ & $9.1 \%$ & - & $6.7 \%$ & \multirow{2}{*}{4} & \multirow{2}{*}{$16 \%$} \\
\hline & 1 & 2 & - & 1 & & \\
\hline \multirow{2}{*}{ Speaking and diction skills } & $3.9 \%$ & $4.6 \%$ & $4.6 \%$ & $6.7 \%$ & 1 & \\
\hline & 1 & 1 & 1 & 1 & 4 & $16 \%$ \\
\hline Customer reiontotion lill & - & $4.6 \%$ & $9.1 \%$ & - & 2 & \\
\hline customer-orientation SkIIS & - & 1 & 2 & - & 3 & $12 \%$ \\
\hline Colution oriontotion oleill & $7.7 \%$ & $4.6 \%$ & - & - & & 1207 \\
\hline solution-orlentation SkIIIS & 2 & 1 & - & - & 3 & $12 \%$ \\
\hline Recult orientation cleillo & $3.9 \%$ & - & $9.1 \%$ & - & 3 & 1207 \\
\hline Result-orientation skIIIS & 1 & - & 2 & - & 3 & $12 \%$ \\
\hline Numerical thinking skills & $7.7 \%$ & - & - & - & 2 & $8 \%$ \\
\hline Numerical thinking skills & 2 & - & - & - & 2 & $8 \%$ \\
\hline & $3.9 \%$ & - & $4.6 \%$ & - & & \\
\hline Decision-making skills & 1 & - & 1 & - & 2 & $8 \%$ \\
\hline Presentation slills & - & $4.6 \%$ & $4.6 \%$ & - & 2 & 807 \\
\hline Presentation skills & - & 1 & 1 & - & 2 & $8 \%$ \\
\hline fearning skills & - & $4.6 \%$ & - & $6.7 \%$ & 2 & 807 \\
\hline LearnIng SKIIIS & - & 1 & - & 1 & 2 & $8 \%$ \\
\hline Stress-manaoement skills & - & - & $4.6 \%$ & $6.7 \%$ & 2 & $80 \%$ \\
\hline stress-management skills & - & - & 1 & 1 & 2 & $8 \%$ \\
\hline & $3.9 \%$ & - & - & - & & \\
\hline Research skills & 1 & - & - & - & 1 & $4 \%$ \\
\hline Process.management skills & $3.9 \%$ & - & - & - & 1 & $4 \%$ \\
\hline Process-management skilis & 1 & - & - & - & 1 & $4 \%$ \\
\hline & $100 \%$ & $100 \%$ & $100 \%$ & $100 \%$ & $100 \%$ & - \\
\hline Iotal number & 26 & 22 & 22 & 15 & 85 & - \\
\hline
\end{tabular}

${ }^{a}$ Finance, auditing, budgeting, funding and liquidity, and credit-related departments.

${ }^{\mathrm{b}}$ Product and process development, information management, private banking, information technology departments and branch management.

second most frequently mentioned skills in finance related, marketing and sales, and other departments, it is the fourth skill after foreign language, communication, and teamwork skills in HR departments. Managers of finance related departments had unique skills requirements of numerical thinking, research, and process-management skills. However, other than these three skills, all the skills were mentioned in at least two or more departments. 


\subsection{Do universities teach their graduates the neces- sary skills?}

Nine managers (36\%) stated that universities do not provide their graduates with the necessary skills to be successful in their jobs in the banking industry, while one manager (4\%) agreed but stated that it is improving over time. Eight managers (32\%) stated that universities do provide their graduates with the necessary skills to be successful in their jobs, while one (4\%) agreed but stated that there is room for improvement. Therefore, 40 percent of managers opined that universities do not provide their graduates with the necessary skills to be successful in their jobs, while 36 percent disagreed. The remaining managers argued that whether new graduates have the necessary skills depends on the individual graduates $(12 \%)$ or the university $(12 \%)$ from which they graduated. Managers' opinions on whether universities teach their graduates the necessary skills are shown in Table 2. Finance managers had definite opinions on the issue and either agreed $(50 \%)$ or disagreed $(50 \%)$ that universities teach their graduates the necessary skills. Marketing and sales managers were less certain and the majority of them $(57 \%)$ stated that whether new graduates have the necessary skills depends on the individual graduates $(12 \%)$ or the university $(12 \%)$ from which they graduated.

Table 2. Managers' opinions on whether universities teach the necessary skills.

\begin{tabular}{|c|c|c|c|c|c|c|}
\hline Opinions & $\begin{array}{c}\text { Finance re- } \\
\text { lated } \\
\text { departments }^{\mathrm{a}}\end{array}$ & $\begin{array}{l}\text { Marketing and } \\
\text { sales depart- } \\
\text { ments }\end{array}$ & $\begin{array}{l}\text { HR depart- } \\
\text { ments }\end{array}$ & $\begin{array}{l}\text { Other depart- } \\
\text { ments }^{b}\end{array}$ & $\begin{array}{l}\text { Total number } \\
\text { of respondents }\end{array}$ & $\begin{array}{c}\text { Percentage of } \\
\text { respondents }\end{array}$ \\
\hline Yes, they do & $\begin{array}{c}50 \% \\
4\end{array}$ & $\begin{array}{c}14.3 \% \\
1\end{array}$ & $\begin{array}{c}20 \% \\
1\end{array}$ & $\begin{array}{c}60 \% \\
3\end{array}$ & 9 & $36 \%$ \\
\hline No, they do not & $\begin{array}{c}50 \% \\
4 \\
\end{array}$ & $\begin{array}{c}28.6 \% \\
2\end{array}$ & $\begin{array}{c}60 \% \\
3\end{array}$ & $\begin{array}{c}20 \% \\
1\end{array}$ & 10 & $40 \%$ \\
\hline $\begin{array}{l}\text { Depends on the individual gradu- } \\
\text { ates }\end{array}$ & - & $\begin{array}{c}28.6 \% \\
2 \\
\end{array}$ & $\begin{array}{c}20 \% \\
1 \\
\end{array}$ & - & 3 & $12 \%$ \\
\hline Depends on the university & - & $\begin{array}{c}28.6 \% \\
2\end{array}$ & - & $\begin{array}{c}20 \% \\
1\end{array}$ & 3 & $12 \%$ \\
\hline Total number of responses & $\begin{array}{c}100 \% \\
8\end{array}$ & $\begin{array}{c}100 \% \\
7\end{array}$ & $\begin{array}{c}100 \% \\
5\end{array}$ & $\begin{array}{c}100 \% \\
5\end{array}$ & $\begin{array}{c}100 \% \\
25\end{array}$ & - \\
\hline
\end{tabular}

${ }^{a}$ Finance, auditing, budgeting, funding and liquidity, and credit-related departments.

${ }^{\mathrm{b}}$ Product and process development, information management, private banking, information technology departments and branch management.

\subsection{The skills for which the managers would like more training to be provided}

The skills for which the managers would like more training to be provided at the universities are summarized in Table 3. Sixteen managers mentioned fifteen separate skills at an average of 1.63 skills per manager (total of 26 responses). The most-frequently stated skills were analytical thinking and research skills, each of which were mentioned by four managers. Other frequently-mentioned skills managers believed universities could do more to provide were computer $(12 \%)$ and communication $(12 \%)$ skills. Of the three managers who sought computer skills, two stated they would like university students to have more training in using MS Office programs, and one wanted more training to improve computer skills in general but did not specify any computer programs. Other less-frequently mentioned skills can be seen Table 3 . It is considered that managers became more forthcoming and shared their opinions more as the interviews continued. Project management $(8 \%)$, time management $(8 \%)$, negotiation $(4 \%)$, organization $(4 \%)$, and business writing (4\%) skills were mentioned by managers as skills for which they would like more training to be provided although they were not specified as skills sought from new graduates. Similarly, research skills were not mentioned by marketing and sales or HR managers, and computer skills were not mentioned by HR managers as skills sought from new graduates although all of these skills are specified as skills for which they would like more training to be provided.

\section{Conclusions}

Results of previous studies have shown that, in terms of new graduate skills, employers seek generic skills that can be applied in a variety of jobs or industries, rather than job-specific skills, and although studies have addressed whether university graduates have the necessary skills to be successful in their jobs, there is a gap in research on this issue in the banking sector. In order to meet the needs of the employers in the banking sector, university students and educators need to know what these needs are. The results of in-depth interviews with twenty-five managers in ten companies in the banking industry in Istanbul, Turkey, show that managers are about evenly 
Table 3. Skills training managers would like universities to provide.

\begin{tabular}{|c|c|c|c|c|c|c|}
\hline Skills mentioned & $\begin{array}{l}\text { Finance related } \\
\text { departments }^{\mathrm{a}}\end{array}$ & $\begin{array}{c}\text { Marketing and } \\
\text { sales } \\
\text { departments }\end{array}$ & $\begin{array}{c}\text { HR } \\
\text { departments }\end{array}$ & $\begin{array}{c}\text { Other } \\
\text { departments }\end{array}$ & $\begin{array}{l}\text { Total number of } \\
\text { respondents }\end{array}$ & $\begin{array}{c}\text { Percentage of } \\
\text { respondents }\end{array}$ \\
\hline \multirow{2}{*}{ Analytical thinking skills } & $25 \%$ & $22.2 \%$ & - & $16.7 \%$ & \multirow{2}{*}{4} & \multirow{2}{*}{$16 \%$} \\
\hline & 1 & 2 & - & 1 & & \\
\hline \multirow{2}{*}{ Research skills } & - & $22.2 \%$ & $28.6 \%$ & - & \multirow{2}{*}{4} & \multirow{2}{*}{$16 \%$} \\
\hline & - & 2 & 2 & - & & \\
\hline \multirow{2}{*}{ Computer skills } & - & $11.1 \%$ & $14.3 \%$ & $16.7 \%$ & \multirow{2}{*}{3} & \multirow{2}{*}{$12 \%$} \\
\hline & - & 1 & 1 & 1 & & \\
\hline \multirow{2}{*}{ Communication skills } & $50 \%$ & - & - & $16.7 \%$ & \multirow{2}{*}{3} & \multirow{2}{*}{$12 \%$} \\
\hline & 2 & - & - & 1 & & \\
\hline \multirow{2}{*}{ Project management skills } & - & $11.1 \%$ & $14.3 \%$ & - & \multirow{2}{*}{2} & \multirow{2}{*}{$8 \%$} \\
\hline & - & 1 & 1 & - & & \\
\hline \multirow{2}{*}{ Time management skills } & - & - & $14.3 \%$ & $16.7 \%$ & \multirow{2}{*}{2} & \multirow{2}{*}{$8 \%$} \\
\hline & - & - & 1 & 1 & & \\
\hline \multirow{2}{*}{ Learning skills } & - & $11.1 \%$ & - & - & \multirow{2}{*}{1} & \multirow{2}{*}{$4 \%$} \\
\hline & - & 1 & - & - & & \\
\hline \multirow{2}{*}{ Teamwork skills } & - & - & $14.3 \%$ & - & \multirow{2}{*}{1} & \multirow{2}{*}{$4 \%$} \\
\hline & - & - & 1 & - & & \\
\hline \multirow{2}{*}{ Negotiation skills } & - & - & $14.3 \%$ & - & \multirow{2}{*}{1} & \multirow{2}{*}{$4 \%$} \\
\hline & - & - & 1 & - & & \\
\hline \multirow{2}{*}{ Organization skills } & $25 \%$ & - & - & - & \multirow{2}{*}{1} & \multirow{2}{*}{$4 \%$} \\
\hline & 1 & - & - & - & & \\
\hline Procentation ckills & - & $11.1 \%$ & - & - & 1 & 107 \\
\hline Presentation skills & - & 1 & - & - & 1 & $4 \%$ \\
\hline Business writing skills & - & - & - & $16.7 \%$ & 1 & 407 \\
\hline Business Writing skills & - & - & - & 1 & 1 & $4 \%$ \\
\hline Crotivitu chill & - & - & - & $16.7 \%$ & 1 & \\
\hline creativity SkIIIS & - & - & - & 1 & 1 & $4 \%$ \\
\hline Whatever skill the individ- & - & $11.1 \%$ & - & - & & \\
\hline ual lacks & - & 1 & - & - & 1 & $4 \%$ \\
\hline Total number of recnencec & $100 \%$ & $100 \%$ & $100 \%$ & $100 \%$ & $100 \%$ & 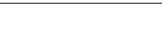 \\
\hline rotal mumber of responses & 4 & 9 & 7 & 6 & 26 & - \\
\hline
\end{tabular}

a Finance, auditing, budgeting, funding and liquidity, and credit-related departments.

${ }^{\mathrm{b}}$ Product and process development, information management, private banking, information technology departments and branch management.

divided between the view that universities do not provide their graduates with the necessary skills to be successful in their jobs and those who think they do $(40 \%$ and $36 \%$, respectively). However, that more than one in three managers find the newly graduated employees lacking in required skills indicates a significant problem. Moreover, the rest of the managers stated that the skills of some new graduates are lacking, as whether the necessary skills are present varies depending on the individual $(12 \%)$ or the individual's alma mater (12\%).

Parallel to previous research, all the skills mentioned by the interviewees were generic skills that can be applied in a range of jobs and can be developed in a range of education programs, which is positive news for both students and educators. The most important skills that managers seek in new graduates are soft skills-communication, teamwork, and interpersonal skills. The next most valued skills are analytical thinking; foreign language skills, especially English since it dominates international communication (Moskvina and Gruževskis 2014); and computer skills, particularly skills with MS Office programs.

The most-frequently mentioned skills in which managers would like the universities to provide more training are analytical thinking, research, computer, and communication skills. Although interpersonal relationship, teamwork, and foreign language skills are on the most desired skills list, they are not high on the list of the skills for which managers would like more training. Similarly, although research skills are not high on the list of desired skills, many managers want more training for that skill. 
Challenged with a shortage of skilled human resources, increasing numbers of companies invest in training and educating their employees (Jurevičienè and Komarova 2010), but both educators and organizations can do more to make prospective employees skilful before they graduate from universities. To meet employers' evolving needs, universities are advised to make innovative changes in their curricula in order to provide training on the skills that will benefit both employers and graduates. Based on the results of this research, to satisfy the needs of organizations in the banking sector, universities should give priority to analytical thinking, research, computer, and communication skills.

However, the responsibility for meeting their human resource needs lies more with the banks than it does with the universities since bank executives are the ones who want their needs met. Bank executives are advised to communicate with faculty deans, university rectors, and governmental officials in higher education to ensure they understand what they need from new graduates and carry out joint projects with them in pursuit of those goals.

Although this study fills a gap in research by exploring what the banking sector needs from new graduates, it has several limitations. The study was carried out with a limited number of managers working in a few organizations in the banking industry in Turkey. To generalize the results, the issue should be studied with more managers in more banks. Moreover, since the issue is important not only for banks but also for all organizations that hire new graduates, it should be studied in other industries as well. In addition, it would be useful if data from a large number of respondents could be collected using quantitative methods, in addition to qualitative methods like in-depth interviews. Moreover, although previous research found that employers' perceptions of the skills graduates need are similar in a variety of cultural contexts, such as the UK, Austria, Slovenia, and Romania (Andrews and Higson 2008), more national studies are needed in order to determine the similarities and differences among cultures in terms of the skills organizations need from new graduate employees. Future researchers are recommended to study the subject with more respondents in more organizations in different counties, and explore the issue by using quantitative methods such as surveys in addition to qualitative methods.

\section{Acknowledgements}

The author would like to thank her students of the course INT 326: Managing Multinational Companies at Istanbul Bilgi University for their contributions to the collection of the data used in this study.

\section{References}

Adebakin AB, Ajadi OT, Subair ST (2015) Required and possessed university graduate employability skills: perceptions of the Nigerian employers. World Journal of Education 5(2): 115-121. https://doi. org/10.5430/wje.v5n2p115

Al Shayeb AM (2013) Finance graduates' knowledge and skills development: graduate and employer perceptions in United Arab Emirates. Journal of Education for Business 88(6): 307-313. https://doi. org/10.1080/08832323.2012.715096

Andrews J, Higson H (2008) Graduate employability, soft skills versus hard business knowledge: a European Study. Higher Education in Europe 33(4): 411-422. https://doi.org/10.1080/03797720802522627

Bachynsky EA, Dale VHM, Kinnison T, Gazzard J, Baillie S (2013) A survey of the opinions of recent veterinary graduates and employers regarding early career business skills. Veterinary Record 172(23): 604. https://doi.org/10.1136/vr.101376

Cicekli E (2015) Turkiye'de bankalarin yeni mezun calisan ihtiyaclari: universiteler mezunlarina gerekli bilgileri kazandiriyor mu? [New graduate employee needs of banks in Turkey: do universities have their graduates attain the necessary knowledge?]. In: Yumusak İG (Ed.) $12^{\text {th }}$ International Conference on Knowledge, Economy and Management Proceedings, 27-30 November 2014, Kemer-Antalya, Turkey. Sera Manyetik Bant Sanayi AS, Istanbul, 897-904. [in Turkish]

Collet C, Hine D, du Plessis, K (2015) Employability skills: perspectives from a knowledge-intensive industry. Education + Training 57(5): 532-559. https://doi.org/10.1108/ET-07-2014-0076

Coetzer A, Sitlington H (2014) What knowledge, skills and attitudes should strategic HRM students acquire? A Delphi study. Asia Pacific Journal of Human Resources 52(2): 155-172. https://doi. org/10.1111/1744-7941.12008

Cook ED, Finch B (1994) Qualities employers seek in new accounting employees. Journal of Education for Business 69(3): 136-139. https://doi.org/10.1080/08832323.1994.10117671

Daud S, Abidin N, Sapuan NM, Rajadurai J (2011) Enhancing university business curriculum using an importance-performance approach: a case study of the business management faculty of a university in Malaysia. International Journal of Educational Management 25(6): 545-569. https://doi.org/10.1108/09513541111159059

Hellier P, Keneley M, Carr R, Lynch B (2004) Towards a market oriented approach: employer requirements and implications for undergraduate economics programs. Economic Papers 23(3): 213-233. https://doi.org/10.1111/j.1759-3441.2004.tb00367.x

Hesketh AJ (2000) Recruiting an elite? Employers' perceptions of graduate education and training. Journal of Education and Work 13(3): 245-271. https://doi.org/10.1080/713676992

Husain MY, Mokhtar SB, Ahmad AA, Mustapha R (2010) Importance of employability skills from employers' perspective. Procedia Social and Behavioral Sciences 7(C): 430-438. https://doi.org/10.1016/j. sbspro.2010.10.059

Jackling B, De Lange P (2009) Do accounting graduates' skills meet the expectations of employers? A matter of convergence or divergence. Accounting Education: an International Journal 18(4-5): 369-385. https://doi.org/10.1080/09639280902719341

Jurevičienė D, Komarova A (2010) Darbuotojo konkurencingumo vertinimo teoriniai aspektai [Theoretical aspects of employee's competitiveness assessment]. Business: Theory and Practice 11(2): 124-133. [In Lithuanian]

Kavanagh MH, Drennan L (2008) What skills and attributes does an accounting graduate need? Evidence from student perceptions and employer expectations. Accounting and Finance 48(2): 279-300. https://doi.org/10.1111/j.1467-629X.2007.00245.x 
Kirk C, Chapman R (1992) Science and technology management: designing an undergraduate course. Research in Science Education 22(1): 255-259. https://doi.org/10.1007/BF02356903

Klibi MF, Oussii AA (2013) Skills and attributes needed for success in accounting career: do employers' expectations fit with students' perceptions? Evidence from Tunisia. International Journal of Business and Management 8(8): 118-132. https://doi.org/10.5539/ijbm.v8n8p118

McMurray S, Dutton M, McQuaid RW; Richard A (2016) Employer demands from business graduates. Education + Training 58(1): 112 132. https://doi.org/10.1108/ET-02-2014-0017

Morley L, Aynsley S (2007) Employers, quality and standards in higher education: shared values and vocabularies or elitism and inequalities? Higher Education Quarterly 61(3): 229-249. https://doi. org/10.1111/j.1468-2273.2007.00353.x

Moskvina J, Gruževskis B (2014) Daugiakalbystẻ kaip verslo plètros veiksnys [Multilingualism as a business development factor]. Business: Theory and Practice 15(1): 22-31 (in Lithuanian). https://doi. org/10.3846/btp.2014.03

Ngoo YT, Tiong KM, Pok WF (2015) Bridging the gap of perceived skills between employers and accounting graduates in Malaysia. American Journal of Economics 5(2): 98-104.

Norwood FB, Henneberry SR (2006) Show me the money! The value of college graduate attributes as expressed by employers and perceived by students. American Journal of Agricultural Economics 88(2): 484-498. https://doi.org/10.1111/j.1467-8276.2006.00873.x

Rassuli A, Bingi P, Karim A, Chang O (2012) A survey of critical knowledge and skills of business school graduates: employer perspectives. The Journal of International Management Studies 7(2): 1-6.

Rivera LA (2011) Ivies, extracurriculars, and exclusion: elite employers' use of educational credentials. Research in Social Stratification and Mobility 29(1): 71-90. https://doi.org/10.1016/j.rssm.2010.12.001

Sodhi MS, Son B-G (2008) ASP, the art and science of practice: skills employers want from operations research graduates, Interfaces 38(2): 140-146. https://doi.org/10.1287/inte.1080.0342

Stankevičienė A, Korsakienė R, Liučvaitienė A (2009) Žmogiškujų išteklių valdymo strategijos rengimo teoriniai ir praktiniai aspektai: Lietuvos telekomunikacijụ sektoriaus atvejis [The theoretical and practical aspects of human resource management strategy development: a case of Lithuanian telecommunication sector]. Business: Theory and Practice 10(4): 276-284. https://doi.org/10.3846/16480627.2009.10.276-284 [in Lithuanian]

Sullivan DW (2012) Manufacturing hiring trends: employers seeking more diverse skills. International Journal of Management \& Information Systems 16(3): 247-254. https://doi.org/10.19030/ijmis. v16i3.7077

Tanyel F, Mitchell MA, McAlum HG (1999) The skill set for success of new business school graduates: do prospective employers and university faculty agree? Journal of Education for Business 75(1): 33-37. https://doi.org/10.1080/08832329909598987

Thomas I, Nicita J (2003) Employers' expectations of graduates of environmental programs: an Australian experience. Applied Environmental Education and Communication 2(1): 49-59. https://doi. org/10.1080/15330150301341 